\title{
VERTICAL STARCH-GEL ELECTROPHORESIS IN SOME RHEUMATIC DISEASES*
}

BY

\author{
A. HOWARD AND BARBARA M. ANSELL \\ M.R.C. Rheumatism Research Unit, Canadian Red Cross Memorial Hospital, Taplow, Maidenhead. Berks.
}

Vertical starch-gel electrophoresis (Smithies, 1959a) produces a much finer separation of the serum proteins than on the familiar paper or cellulose acetate electrophoretic strip where human serum divides into albumin, $x_{1}, x_{2}, \beta^{2}$, and $\gamma$-globulins. On vertical starch-gel, the pattern becomes more complex consisting of pre-albumin, acidic $\alpha_{1}$-glycoprotein, albumin, $x_{1}$-globulin, $x_{2}$-globulin, $x_{2}$-globulin, haptoglobin, $\alpha_{2}$-globulin, $\beta$-globulin, $\beta$-globulin or transferrin, haptoglobins, slow $\gamma_{2}$-macroglobulin, -lipoprotein, application slot, and $\gamma$-globulin (Fig. 1). The different order of the bands compared with their order on paper is due to the sieving effect of the gel pores being superimposed on the normal electrical effects of the applied voltage.

In a preliminary study of starch-gel patterns in rheumatic diseases, using sera from twelve patients with rheumatic fever, twelve with rheumatoid arthritis, twelve with Still's disease, and two with ankylosing spondylitis, an intense diffuse-edged band in the $\alpha_{2}$-globulin region (Fig. 2, opposite) was found in five sera from patients with Still's disease and in one from a patient with rheumatoid arthritis. It was decided to investigate this phenomenon further.

\section{Plan of Study}

Vertical starch-gel electrophoresis was therefore carried out on sera from ninety unselected cases of definite Still's disease (Ansell and Bywaters, 1959) who were in-patients at the time or attending follow-up clinics, thirty patients with ankylosing spondylitis as defined by limitation of back movement with radiological evidence of sacro-iliitis and spinal abnormalities, and thirty patients with classical rheumatoid arthritis (A.R.A. Criteria: Ropes, Bennett, Cobb, Jacox, and Jessar, 1959). Eighty sera taken from a population survey were used as healthy controls. Full details of the clinical state, including differential agglutination test (D.A.T.), latex test, and therapy, were available, and these

\footnotetext{
* Paper read at the Annual General Meeting of the Heberden Society in December, 1963.
}

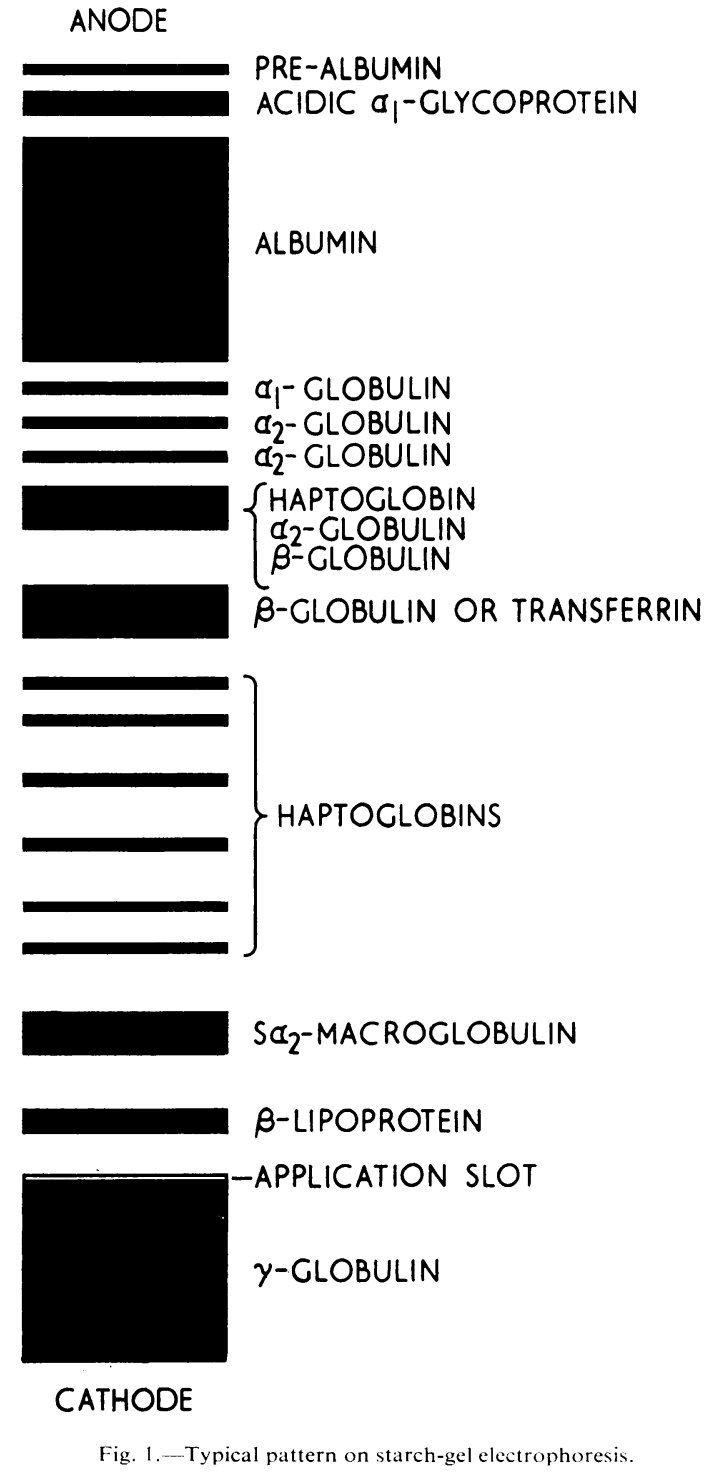




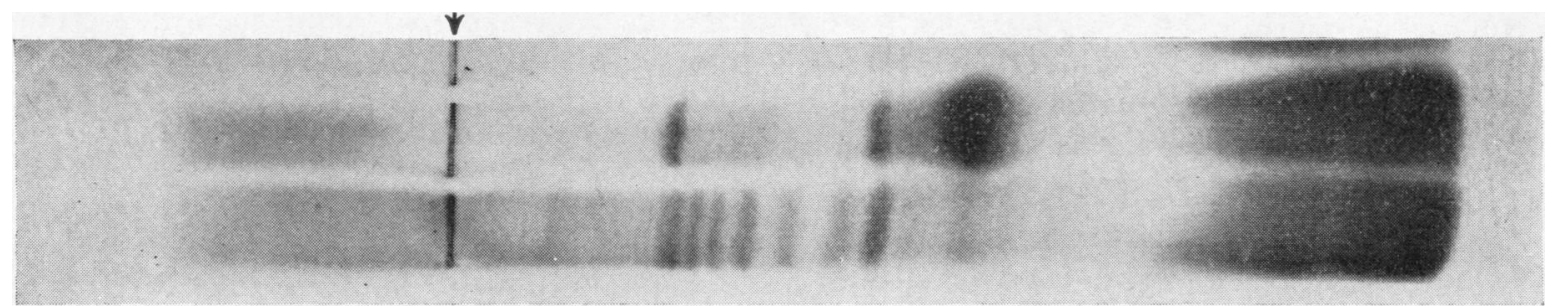

Fig. 2.-Starch-gel electrophoresis. $\quad \boldsymbol{\nabla}=$ application slot

Left strip: Serum from case of Still's disease with Hp. 1-1 grouping, showing intense band in $\alpha_{2}$-globulin region. Right strip: Normal serum of Hp. 2-1 group.

were analysed for all the patients and the population sample.

\section{Results}

After careful examination of the starch-gel patterns, a very faint band at the same site as in the pilot study was noted in four ( 5 per cent.) of the controls. The haptoglobin distribution in the sera from the population survey was as expected (Smithies, 1959b).

Among the ninety cases of Still's disease, nineteen (21 per cent.) showed an intensely-staining band. An unexpected finding was that 38 (42 per cent.) showed the haptoglobin group 1-1, as compared with 16 per cent. in the control population.

In the group with ankylosing spondylitis, 20 per cent showed this unknown band, while in two cases a strong band in the fast gamma region was also detected (Fig. 3). One of these had had deep $x$-ray therapy 8 years previously. The haptoglobin distribution in this small group could not be regarded as significantly different from the population group.

Similarly among the patients with rheumatoid arthritis, 20 per cent also showed this intenselystaining band in the $\alpha_{2}$-globulin region; again the smallness of the sample does not allow adequate interpretation of the haptoglobin group distribution (Table).

There appeared to be no correlation of this $\alpha_{2}$-globulin band with age, sex, clinical disease activity, or type of therapy; nor was there a correlation with a positive D.A.T. or latex test, or with $\alpha_{2}$-globulin levels as seen on paper electrophoresis, or caeruloplasmin.

\section{Discussion}

The more complete study did not confirm that this intensely-staining band was unique to patients suffering from Still's disease, as it was found in 20 per cent. of all the rheumatic cases studied. It does

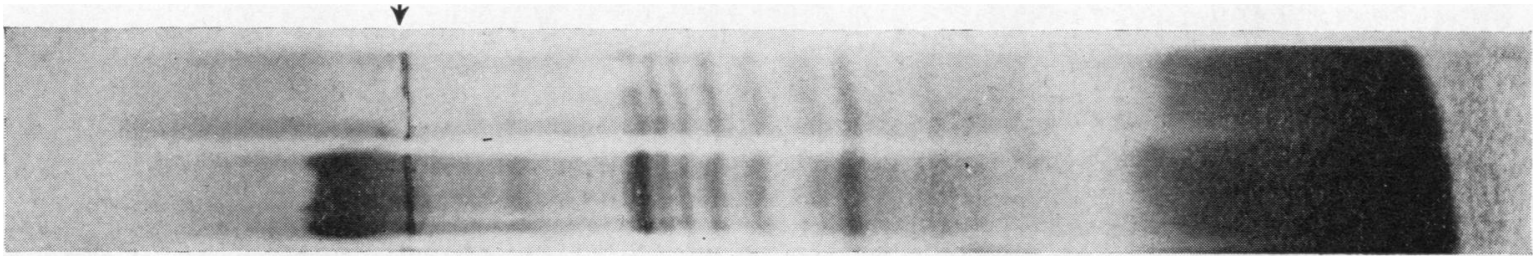

Fig. 3.-Starch-gel electrophoresis. $\quad \boldsymbol{\nabla}=$ application slot

Left strip: Normal serum.

Right strip: Serum from ankylosing spondylitis case, showing fast gamma globulin band.

TABLE

Distribution of Haptoglobin Groups, by Diagnosis.

\begin{tabular}{|c|c|c|c|c|c|c|c|}
\hline Diagnosis & $\cdots$ & $\cdots$ & $\cdots$ & Still's Disease & $\begin{array}{l}\text { Ankylosing } \\
\text { Spondylitis }\end{array}$ & $\begin{array}{c}\text { Rheumatoid } \\
\text { Arthritis }\end{array}$ & Controls \\
\hline Total No. of Cases & . & . & $\cdots$ & 90 & 30 & 30 & 80 \\
\hline Sex & & $\underset{\text { Female }}{\text { Male }}$ & $\dot{m}$ & $\begin{array}{l}30 \\
60\end{array}$ & $\begin{array}{r}24 \\
6\end{array}$ & $\begin{array}{r}9 \\
21\end{array}$ & $\begin{array}{l}38 \\
42\end{array}$ \\
\hline $\begin{array}{l}\text { Haptoglobin } \\
\text { Groups } \\
\text { (per cent.) }\end{array}$ & & $\begin{array}{l}1-1 \\
2-1 \\
2-2\end{array}$ & & $\begin{array}{l}42 \\
34 \\
24\end{array}$ & $\begin{array}{l}23 \\
44 \\
33\end{array}$ & $\begin{array}{l}23 \\
13 \\
64\end{array}$ & $\begin{array}{l}16 \\
45 \\
39\end{array}$ \\
\hline \multicolumn{4}{|c|}{ Percentage with Unknown Spot } & 21 & 20 & 20 & 5 \\
\hline
\end{tabular}


not appear to have been described previously in patients with rheumatic disorders and it was felt that it was probably related to the underlying disorder, as the four examples found in the control group were in small amount and were detectable only on very careful review. During examination of more than 100 sera from patients of all ages in this hospital with a variety of disorders, including diabetes, haemolytic anaemia, uraemia, tuberculosis, and neoplasms, where changes in the serum proteins might be expected, only one has shown a similar band. This was a case of pulmonary tuberculosis with a very low serum albumin, who had marked albuminuria and was suspected of having renal amyloidosis. In view of this, the patients with rheumatic disorders were reviewed for the presence of amyloidosis, but a band was found in only one of the seven patients with this complication, nor could it be detected in a few cases of amyloidosis from other causes who were then studied. A protein band in a similar position has, however, been described by Fraser, Harris, and Robson (1959) in one family; they noted this in patients who had both goitre and deafness and who were being studied for a possible genetic background. To investigate a genetic trait, the sera from the families of six of the cases of Still's disease were studied. Three probands had the unknown band but it was not present in the other three. No band was found in the parents or siblings of the three probands with the band, but it was present in the mother of one of the probands without the band, and this mother is herself suffering from sero-positive rheumatoid arthritis.

Although no genetic trait could be detected as regards the unidentified band in this small series of families, the significantly high proportion of haptoglobin 1-1 group in the patients with Still's disease does suggest that genetic factors may be involved in Still's disease. The haptoglobins have been shown by Smithies and Walker (1955) to be under simple genetic control of a single autosomal (i.e. not sexlinked) locus occupied by either one of a pair of alleles, called by Smithies $\mathrm{Hp}_{1}$ and $\mathrm{Hp}_{2}$. The frequencies in our control population agree with the frequencies quoted by Smithies (1959b). Allison and Blumberg (1958) reported finding the haptoglobin groups in 35 patients with rheumatoid arthritis and in 183 controls using horizontal starch-gel electrophoresis. Their controls differed slightly from those of Smithies and they found 67 per cent. of their rheumatoid patients to have $\mathrm{Hp} \mathrm{2-1}$ grouping. This is at variance with our findings, but it is unwise to draw conclusions from such a small series. Cohen and Chasen (1963) investigated the haptoglobin groups of 45 Caucasian males suffering from ankylosing spondylitis and their distribution of $\mathrm{Hp}$ groups is very similar to that of the present survey.

The sharp peak in the fast gamma globulin region seen in two of our cases with ankylosing spondylitis does not seem to have been recorded previously. Neither of these patients showed clinical signs of myelomatosis complicating their ankylosing spondylitis. Similar bands have been recorded as occuring very rarely in health and in a variety of diseases (Owen and Got, 1960; Engle, Woods, Castillo, and Pert, 1961). Further work is now in progress to isolate these proteins.

\section{Summary}

(1) In a pilot study of vertical starch-gel electrophoresis in rheumatic fever, ankylosing spondylitis, rheumatoid arthritis, and Still's disease, a significant proportion of patients with Still's disease appeared to have an intense protein band in the post-albumin region.

A more detailed study of thirty patients with rheumatoid arthritis, thirty with ankylosing spondylitis, and ninety with Still's disease showed this band to occur in 20 per cent. of all patients with these rheumatic diseases, but in only 5 per cent. in controls in whom the band was very much weaker. This is a significant difference. This did not appear to be related to therapy, age, sex, or amyloidosis. There was no evidence of inheritance in a small group of families studied.

(2) In two of the thirty cases of ankylosing spondylitis a fast gamma-globulin band was found resembling a myeloma protein.

(3) A significantly high proportion of haptoglobin group 1-1 was found among the ninety cases of Still's disease studied.

\section{REFERENCES}

Allison, A. C., and Blumberg, B. S. (1958). Arthr. and Rheum., 1, 239.

Ansell, B. M., and Bywaters, E. G. L. (1959). Bull. rheum. Dis., 9, 189.

Cohen, A. S., and Chasen, W. (1963). Proc. Soc. exp. Biol. (N.Y.), 114, 698.

Engle, R. L., Jr., Woods, K. R., Castillo, G. B., and Pert, J. H. (1961). J. Lab. clin. Med., 58, 1.

Fraser, G. R., Harris, H., and Robson, E. B. (1959). Lancet, 1, 1023.

Owen, J. A., and Got, C. (1960). J. clin. Path., 13, 58.

Ropes, M. W., Bennett, G. A., Cobb, S., Jacox, R., and Jessar, R. A. (1959). Ann. rheum. Dis., 18, 49.

Smithies, O. (1959a). Biochem. J., 71, 585.

(1959b). Adv. Prot. Chem., 14, 65.

and Walker, N. F. (1955). Nature (Lond.), 176, 1265. 


\section{DISCUSSION}

DR. A. ST. J. Dixon (Kensington): I wonder if you have been able to exclude $C$-reactive protein as the unknown blob?

DR. HowARD: I have not run specifically for C-reactive protein, but it is probably a $\gamma$-globulin.

Dr. J. S. LAWRENCE (Manchester): Have you looked for this blob in other diseases?

Dr. Howard: Yes, with particular emphasis on the inflammatory diseases and cases of amyloidosis. I found it in only one patient.

A SPEAKER: Have you any knowledge of what would appear on immuno-electrophoresis?

DR. HowARD: Technically, there are rather more difficulties with starch-gel immuno-electrophoresis, and agar-gel immuno-electrophoresis which has been done does not give the same pattern.

Dr. W. A. Bourne (Hove): Did you find this pattern in Felty's syndrome?

DR. Howard: We only had one case of Felty's syndrome, and there we did not find it.

\section{Electrophorèse verticale sur amidon-gel dans quelques maladies rhumatismales}

\section{RÉSUMÉ}

(1) Une étude préliminaire de l'électrophorèse verticale sur amidon-gel dans le rhumatisme articulaire aigu, la spondylarthrite ankylosante, l'arthrite rhumatismale et dans la maladie de Still révéla qu'un nombre appréciable des malades atteints de maladie de Still semblait avoir une bande intense de protéine au delà de la région d'albumine.

L'examen plus détaillé de 30 cas d'arthrite rhumatis- male, 30 de spondylarthrite ankylosante et 90 de maladie de Still montra l'existence de cette bande en 20 pour cent de tous les malades atteints de ces affections rhumatismales, mais seulement en 5 pour cent des témoins, chez qui la bande était beaucoup plus faible. Cette différence est bien significative. La thérapie, l'âge, le sexe ou l'amyloïdose n'y semblaient jouer aucun iôle. On ne trouva pas de preuves de transmission héréditaire dans les familles étudiées.

(2) Dans 2 cas sur 30 de spondylarthrite ankylosante on trouva une bande rapide de globuline gamma, ressemblant à une protéine myélomateuse.

(3) Un taux appréciablement élévé d'haptoglobine, groupe 1-1, fut trouvé parmi les 90 cas étudiés de maladie de Still.

\section{Electroforesis vertical sobre almidón-gel en algunas enfermedades reumáticas}

\section{Sumario}

(1) Un estudio preliminar de la electroforesis vertical sobre almidón-gel en el reumatismo poliarticular agudo, la espondilartritis anquilosante, la artritis reumatoide y en la enfermedad de Still reveló que un número apreciable de pacientes con la enfermedad de Still pareció tener una banda intensa de proteina fuera de la región de albumina.

Un estudio más detallado de 30 casos de artritis reumatoide, 30 de espondilartritis anquilosante y 90 de enfermedad de Still evidenció esta banda en el 20 por ciento de todos los pacientes con estas enfermedades reumáticas, pero sólo en el 5 por ciento de los testigos, en los cuales esta banda fué debilísima. Esta diferencia es significativa. La terapia, la edad, el sexo y la amiloidosis no parecieron jugar papel alguno. No se encontraron pruebas de transmissión hereditaria en el pequeño grupo de familias estudiadas.

(2) Entre 30 casos de espondilartritis se encontraron dos con una banda rápida de globulina gamma que se pareció a una proteina mielomatosa.

(3) Valores significativamente altos de haptoglobina, grupo 1-1, fueron encontrados entre los 90 casos estudiados de enfermedad de Still 